\title{
DANO MORAL: PROTEÇÃO JURÍDICA À SAÚDE DO TRABALHADOR
}

\author{
Ana Célia Bohn \\ Universidade Regional de Blumenau - FURB \\ anaceliabido@gmail.com \\ Eliane Chaves Camilo Leite \\ Centro Universitário Católica de Santa Catarina \\ eliane.leite@catolicasc.org.br \\ Isabel Cristina Bohn Vieira \\ Faculdade de Ciências Sociais Aplicadas - CELER \\ isabelbohnvieira@gmail.com \\ Recebido em: 07 fev. 2019 \\ Aceito em: 23 set. 2019
}

Como citar este artigo: BOHN, Ana Célia; LEITE, Eliane Chaves Camilo; BOHN VIEIRA, Isabel Cristina. DANO MORAL: PROTEÇÃO JURÍDICA À SAÚDE DO TRABALHADOR. Revista Visão:

Gestão Organizacional, Caçador, SC, Brasil, p. 62-78, set. 2019. ISSN 2238-9636. Disponível em: <http://dx.doi.org/10.33362/visao.v8i2.1915>.

Resumo: Desde a Constituição Federal de 1988, na qual se reconhece a "dignidade da pessoa humana" e os "valores sociais do trabalho" percorre-se um longo caminho até que isso realmente se concretize. Nesta discussão teórica, aborda-se o significado de dano moral, sua importância e seus efeitos na saúde do trabalhador, a atenção jurídica dispensada ao assunto e a banalização do conceito da ofensa à dignidade na busca de recursos indevidos. Quando a ofensa à dignidade se torna passível de indenização de dano moral? Como a justiça do trabalho mensura o dano psicológico? Objetivou-se com o estudo analisar como o dano moral afeta a saúde física e mental, desenvolvendo sintomas silenciosos e graves, podendo levar o trabalhador ao suicídio, e conhecer como a esfera judiciária trabalhista tem tratado o assunto. Buscou-se com essa problemática, por meio da pesquisa bibliográfica com o método indutivo para demonstrar os dispositivos legais utilizados pelos magistrados para julgar casos de dano moral e preservar os direitos personalíssimos do trabalhador.

Palavras-Chave: Dano moral. Justiça do trabalho. Saúde do trabalhador.

\section{MORAL DAMAGE: LEGAL PROTECTION OF WORKER'S HEALTH}

Abstract: Since the Federal Constitution of 1988, which recognizes the "dignity of the human person" and the "social values of work", it goes a long way until this really materializes. This theoretical discussion addresses the meaning of moral damage, its importance and its effects on the health of the worker, the legal attention given to the subject and the banalization of the concept of offense to dignity in the search for undue resources. When does the offense against dignity become liable to compensation for moral damages? How does labor justice measure psychological damage? The objective of this study was to analyze how moral damage affects physical and mental health, developing silent and serious symptoms, which can lead the worker to suicide, and to know how the labor judicial sphere has dealt with the subject. We sought this problem 
through the literature search with the inductive method to demonstrate the legal devices used by magistrates to judge cases of moral damage and preserve the most personal rights of the worker.

Keywords: Moral damage. Work justice. Worker's healt.

\section{INTRODUÇÃO}

O assédio moral vem sendo considerado o mal do século, como consequência das dificuldades que as pessoas têm em se relacionarem e de empregadores em manter o poder diretivo focado no respeito ao contrato de trabalho à luz da legislação. A questão do dano moral nas relações de trabalho é uma avalanche que está atingindo empregados, produzindo desvios de comportamento, estresse e doenças psicossomáticas refletindo significativamente na qualidade de vida laboral.

O dano moral é a maneira mais clássica que descreve situações constrangedoras no processo laboral sistemático e contínuo, evidenciando fatos desagradáveis vivenciados no local de trabalho. De acordo com Rufino (2011) o assédio moral se origina quando o empregado expõe o seu senso crítico, agindo ou expressando sua opinião de forma diferente do que o esperado pelo empregador.

O entendimento equivocado do assédio moral tem provocado uma avalanche de reclamatórias trabalhistas e quando configurado por um evento isolado, revoltado o empregado busca indenização na justiça, banalizando desta forma o assédio moral. Ele deve ser entendido como uma dor, um sofrimento ou humilhação que, fugindo à normalidade, interfere no comportamento físico e psicológico do ser humano, causando desequilibro, ferindo sua integridade psíquica.

Para Felker (2006, p. 18) "dano moral é todo ato que atinge direitos da personalidade do trabalhador, empregador, como pessoa física, de pessoa jurídica empregadora ou da coletividade, decorrente de violação à liberdade, honra, dignidade, intimidade, imagem, reputação, bom nome profissional e empresarial".

Presume-se boa fé objetiva nas relações de trabalho porém, a primazia da realidade não corresponde com a real face da verdade formal. Qual a influências dessas atitudes na saúde física e mental do trabalhador? As doenças físicas podem facilmente ser diagnosticadas por exames médicos e as doenças psicossomáticas, como podem ser mensuradas pela justiça do trabalho?

Na Constituição da República Federativa do Brasil (CRFB) promulgada em 05 de outubro de 1988, o dano moral é aquele que decorre da violação à dignidade da pessoa humana e uma vez que o meio ambiente do trabalho saudável é um direito fundamental, neste contexto percebe-se a importância do assunto e a relevância que ele apresenta para a legislação trabalhista. 
Segundo Cunha Filho (2012) "nosso ordenamento jurídico pátrio trata a matéria com máxima eficiência, à jurisprudência dominante vem entendendo que o mero descumprimento de obrigações trabalhistas não enseja, por si só, a indenização por dano moral". Se presa principalmente pela veracidade dos fatos e integridade do trabalhador.

À luz destas conjecturas, esse artigo tem por objetivo geral "analisar como o dano moral afeta a saúde física e mental nas relações de trabalho", e, como objetivos específicos: a análise de como a justiça do trabalho tem abordado o assunto e, descrever se há violação da dignidade humana, a partir do princípio da boa fé objetiva.

A motivação para tal estudo se concebe diante das crescentes ações trabalhistas por dano moral e o anseio pelo conhecimento de como a justiça trabalhista se propõe a proteger a saúde do trabalhador no âmbito organizacional, preservando assim os direitos personalíssimos.

Destarte, apoiar os estudos na área de administração dentro da teoria crítica (ALCADIPANI; TURETA, 2009), a fim de, evoluir as discussões neste pleito, sugerindo o acompanhamento das classes desprovidas de poder e o comportamento da sociedade pósmoderna quanto às relações de trabalho.

\section{METODOLOGIA}

A metodologia de um trabalho científico traduz um conjunto de processos pelos quais o pesquisador procura conhecer determinadas situações, procurando fundamentar suas ideias durante o desenvolvimento de sua pesquisa.

A pesquisa pode ser determinada como "um procedimento formal, com métodos de pensamento reflexivo, que requer um tratamento científico e se constitui no caminho para se conhecer a realidade ou para descobrir verdades parciais" (LAKATOS e MARCONI, 2006). Portanto, o método significa: o conjunto das atividades sistemáticas e racionais que, com maior segurança e economia, permite alcançar o objetivo - conhecimento válido e verdadeiro traçando o caminho a ser seguido, detectando erros e auxiliando as decisões do cientista. (LAKATOS; MARCONI, 2006).

Enquanto natureza de pesquisa, trata-se de discussão teórica e empírica, utilizando método indutivo e tem como objetivo a pesquisa bibliográfica, a qual "procura explicar um problema a partir de referências teóricas publicadas em documentos" (CERVO e BERVIAN, 1996), para identificar os fatores que o dano moral provoca e como afeta a saúde física e mental dos trabalhadores, conhecendo e analisando os dispositivos legais e sua aplicabilidade na legislação trabalhista. Minayo (2002) descreve que este tipo de pesquisa, trabalha com o mundo de significados, motivos, aspirações, crenças, valores e atitudes, o que corresponde a um espaço mais profundo de relações.

Buscou-se na pesquisa bibliográfica, de cunho cientifico, o conhecimento das causas 
e efeitos do dano moral na saúde física e mental do trabalhador e o posicionamento da esfera trabalhista, a qual tem a função específica de proteção ao trabalhador, com o apoio do método de indução, nos anos de 2017 e 2108, com observância às práticas jurisprudenciais deste período.

\section{DISCUSSÃO TEÓRICA}

Quando se fala em dano moral é difícil imaginar que eventos de humilhação verbal e física aconteçam nos ambientes laborais, em um momento onde tanto se difunde a importância dos talentos humanos para as organizações. O que se verifica com esse cenário é que além de gerar renda o trabalho é uma extensão de lares, extensão de família, aonde se busca respeito e reconhecimento.

O dano moral tipifica a precariedade nas relações de emprego, o despreparo profissional dos empregadores, a falta de conhecimento em gestão e principalmente o desequilíbrio e a insensatez na utilização do poder diretivo. O dano moral pode adoecer física e psicologicamente, desmotivar e desestabilizar profissionais que poderiam ser potencias produtivas se devidamente estimulados. Qual o verdadeiro valor dispensado à dignidade da pessoa humana? Ela nasce com o indivíduo e a função do Estado é proteger, reconhecer e garantir essa dignidade por meio das leis.

Evidencia-se que há dispositivos na lei que garantem essa proteção ao trabalhador, quando de fato ele denuncia o abuso sofrido. A legislação trabalhista tem se mostrado eficiente e produtiva com relação aos julgados pelo dano moral e o assédio moral, respeitando à dignidade da pessoa humana, reconhecendo os meios de valorização do trabalho e objetivando promover o bem-estar e a justiça social.

\section{DANO MORAL NO DIREITO DO TRABALHO}

O dano moral acontece quando a conduta do empregador prejudica intencionalmente a intimidade, a moral ou a privacidade, promovendo constrangimento e humilhação pública, onde se presume o sofrimento, dor, angústia, tristeza, entre outros danos de ordem psíquica, causando um prejuízo direto à dignidade do trabalhador.

Sob outra perspectiva, o "dano moral é o que atinge o ofendido como pessoa, não lesando seu patrimônio. É lesão de bem que integra os direitos da personalidade, como a honra, a dignidade, intimidade, a imagem, o bom nome, etc., como se infere dos art. 1으, III, e 5o, V e X, da Constituição Federal, e que acarreta ao lesado dor, sofrimento, tristeza, vexame e humilhação" (GONCALVES, 2009, p. 359).

Para o Médico Psiquiatra Hewdy Lobo "considera-se Dano Moral quando um indivíduo sente-se afetado em seu ânimo psíquico, moral e intelectual, seja por acometimento à sua 
honra, privacidade, intimidade, imagem, nome ou em seu próprio corpo físico, e poderá estender-se ao dano patrimonial se a ofensa de alguma forma impedir ou dificultar atividade."

O dano moral é o menosprezo sofrido por alguém como consequência de palavras ilícitas ou atividades de risco desenvolvidas, capaz de atingir direitos da personalidade. É considerado como qualquer ofensa à dignidade humana.

Existe uma íntima relação entre o dano moral e o assédio moral, de acordo com a Advogada Fernanda de Carvalho Serra (2017) "existe uma distinção entre o dano psíquico (assédio) e o dano moral. O primeiro, por meio de uma alteração psicopatológica comprovada, e o segundo, na lesão a direitos da dignidade (personalidade)".

Existem diversas situações nas relações empregatícias que podem caracterizar e o dano moral, como: a ofensa à honra do empregado, a acusação infundada de furto na empresa, comentários difamantes do empregador em relação à conduta pessoal e profissional do empregado com o objetivo de prejudicá-lo dentro da empresa, ou até mesmo depois da rescisão do contrato na busca de um novo emprego. E, situações que acontecem no ambiente laboral que podem ensejar um dano moral ou um assédio moral permanente.

Observa-se que na Justiça do Trabalho, a doutrina se posiciona de maneira a indicar alguns pontos, que sugerem haver diferença entre dano moral e assédio Moral. Neste leque de disposições, é caracterizado um esforço da Justiça do Trabalho para alinhar direito e ética nas relações laborais. Conforme Felker (2006, p. 18) “dano moral é todo ato que atinge direitos da personalidade do trabalhador, empregador, como pessoa física, de pessoa jurídica empregadora ou da coletividade, decorrente de violação à liberdade, honra, dignidade, intimidade, imagem, reputação, bom nome profissional e empresarial". O dano moral é de responsabilidade civil e implica em reparação.

No Código de Processo Civil (2002), art. 927 dispõe-se: “Haverá obrigação de reparar o dano, independente de culpa, nos casos especificados em lei, ou quando a atividade normalmente desenvolvida pelo autor do dano implicar, por sua natureza, risco para os direitos de outrem".

Após longo tempo e diversas petições por dano moral, a Justiça do Trabalho entendeu a abrangência do conceito do dano moral, pois em muitos casos não há a ocorrência de sofrimento ou dor que afete o psicossomático da pessoa, porém não deixa de violar os direitos da personalidade do ser humano. Atualmente a Justiça do Trabalho entende pacificamente que ficando caracterizado dano moral é desnecessária a comprovação do dano patrimonial, gerando indenização por si só.

ASSÉDIO MORAL OU MOBBING

O assédio moral nas relações de trabalho é caracterizado por situações de humilhação 
e degradação do ser humano afetando seu psicológico de forma contínua, denegrindo sua honra e imagem diante das pessoas ou da sociedade.

Segundo a Juíza Sônia das Dores Dionízio "a tortura psicológica destinada a golpear a autoestima do empregado, visando forçar sua demissão ou apressar sua dispensa através de métodos que resultem em sobrecarregar o empregado de tarefas inúteis, sonegar-lhe informações e fingir que não os vê, resultam em assédio moral, cujo efeito é o direito à indenização por dano moral, porque ultrapassa o âmbito profissional, eis que minam a saúde física e mental da vítima e corrói a sua autoestima. No caso dos autos, o assédio foi além, porque a empresa transformou o contrato de atividade em contrato de inação, quebrando o caráter sinalagmático do contrato de trabalho, e por consequência, descumprindo a sua principal obrigação que é a de fornecer trabalho, fonte de dignidade do empregado". (TRT 17ạ Região - RO 1315.2000.00.17.00.1 - Ac. 2276/2001 - Rel. Juíza Sônia das Dores Dionízio 20/08/02).

Nas relações de trabalho o empregador possui o poder diretivo, no qual norteia e estabelece o modo pelo qual conduzirá seus negócios, orientando seus empregados como devem executar os serviços, uma vez que, este deverá respeitar as normas internas da empresa. As condutas do empregador violam a integridade humana de forma a humilhar, caracterizando assim o assédio moral, deturpando o comportamento e a auto estima do colaborador. Há no assédio moral fatores de extrema relevância: "o assédio moral agrega dois fenômenos: o abuso de poder e a manipulação perversa.

O primeiro é de fácil percepção e nem sempre aceito pelo empregado, já o segundo, causa grandes devastações e instala-se de maneira perspicaz, o assediador submete à vítima a repetidas humilhações e hostilidade colocando-a em situação de inferioridade". (MINARDI, 2010 apud HIRIGOYEN, 2003, p. 65). As consequências que o assédio moral provoca são inúmeras, atingindo desde a saúde física e mental até a vida social e financeira gerando déficit de produtividade.

Uma dessas consequências é o mobbing laboral que significa "tratar mal" e pode acontecer de três maneiras diferentes, do empregador para com os empregados, entre colegas de trabalho, e também quando o ato acontece dos subordinados para com o empregador. Acontecem através de críticas, desqualificação e isolamento da pessoa e visa intimidar e manipular o empregado através do medo do desemprego.

Com o mobbing o empregado é pressionado psicologicamente a trabalhar além da própria capacidade, deixando de lado a vida social, família e amigos, dedicando-se intensamente ao trabalho, por medo de perder o emprego. A competitividade é estimulada de maneira destrutiva e muitos profissionais reproduzem os abusos e excessos do assediador.

O assédio pode provocar um estresse psicológico severo, uma sensação de se vivenciar um verdadeiro terror, causando a Síndrome de Burnout. Predominante no ambiente 
de trabalho, a síndrome é uma forma de estresse crônico que pode levar a pessoa ao suicídio.

Segundo Moraes (2013) "a Síndrome de Burnout é uma consequência às pessoas que são assediadas moralmente. Burnout significa 'estar acabado"”. E que, "o mobbing é um fenômeno silencioso e uma realidade no mercado de trabalho. Severo, assim como o capitalismo se apresenta". O mobbing no trabalho define a violência pessoal, moral e psicológica. Ele pode desencadear outros problemas relacionados à saúde ocupacional.

Camargo (2011) afirma que "a violência praticada não é percebida porque o agressor é refinado. No entanto, é caracterizado precisamente pela frequência e duração dos ataques à vítima. Por isso que alguns autores denominam de terror psicológico". O assédio moral provoca o desequilíbrio emocional e mental no ambiente laboral, podendo ocasionar patologias mais graves que tem consequências psicopatológicas, psicossomáticas e comportamentais, tais como se descreve ao Quadro 1.

Quadro 1 - Sintomas físicos, psicológicos e comportamentais

\begin{tabular}{l|l|l}
\hline \multicolumn{1}{c|}{ Sintomas Físicos } & \multicolumn{1}{c}{ Sintomas Psíquicos } & \multicolumn{1}{c}{ Sintomas Comportamentais } \\
\hline Fadiga & Dificuldades de concentração & Irritabilidade e impaciência \\
\hline Distúrbio do sono & Lapsos de memória & Perda de interesse laboral \\
\hline Hipertensão arterial & Mudança de humor & Negligência laboral \\
\hline Taquicardia & Raciocínio lento & Isolamento social \\
\hline Cefaléias e enxaquecas & Depressão e estresse & Agressividade \\
\hline Transtornos alimentares e & Tristeza imotivada & Insubordinação \\
gastrointestinais & & \\
\hline Dores musculares & Ansiedade & Absenteísmo injustificado \\
\hline Imunodeficiência & Destruição identidade & Queda na produtividade \\
\hline Fonte: Adaptado &
\end{tabular}

Fonte: Adaptado de Hirigoyen ( 2003).

Rufino (2011) relata que a "saúde de um indivíduo depende do equilíbrio no bem-estar biológico, psicológico e social, razão pela qual, a ocorrência de um desequilíbrio propiciado pelos citados estímulos, certamente afetará o bem-estar da pessoa humana".

O dano moral reflete todos os setores da vida e em casos mais graves o estado depressivo pode levar a pessoa a cometer suicídio. Para chegar a esse estágio, possivelmente ele já apresentou diversos sintomas, inclusive o desinteresse pela própria vida. Barreto (2003) afirma que o assédio moral constitui em um grave risco à saúde psíquica da vítima, uma vez que gera grande tensão psicológica, angústia, medo, sentimento de culpa, provocando uma desarmonização das emoções. Nestas circunstâncias, o empregado perde o conceito de padrões de normalidade no ambiente laboral, tornando-se perceptível o comportamento diferenciado, a falta de interesse pelas funções e a redução na produtividade.

\section{TUTELA DOS DIREITOS PERSONALÍSSIMOS}

O texto da Constituição Federal de 1988 no art. 5․ cita que todos são iguais perante a lei, sem distinção de qualquer natureza, garantindo-se aos brasileiros e aos estrangeiros 
residentes no País a inviolabilidade do direito à vida, à liberdade, à igualdade, à segurança e à propriedade. Conforme Nascimento (2009) os direitos de personalidade são:

prerrogativas de toda pessoa humana pela sua própria condição, referentes aos seus atributos essenciais em suas emanações e prolongamentos, são direitos absolutos, implicam num dever geral de abstenção para a sua defesa e salvaguarda, são indisponíveis, intransmissíveis, irrenunciáveis e de difícil estimação pecuniária.

Os direitos personalíssimos possuem características diferenciadas, na medida em que são destinados à proteção da dignidade humana do trabalhador e as normas jurídicas que norteiam essa proteção é a própria CRFB (1988), a CLT (Consolidação das leis do trabalho) dispersas e, o Direito Civil. O Código Civil faz referência no processo hermenêutico de interpretação e aplicabilidade das normas justrabalhistas, pelo intérprete e aplicador do Direito do Trabalho. Neste pleito, Barros (1997), explica que:

Embora o Direito do Trabalho não faça menção aos direitos à intimidade e à privacidade, por constituírem espécies dos "direitos da personalidade" consagrados na Constituição, são oponíveis contra o empregador, devendo ser respeitados, independentemente de encontrar-se o titular desses direitos dentro do estabelecimento empresarial. É que a inserção do obreiro no processo produtivo não Ihe retira os direitos da personalidade, cujo exercício pressupõe liberdades civis.

Interpretar esse direito é salutar, até mesmo para que se defina quais são os direitos e as obrigações de cada ser humano e qual o limite de uma pessoa para a outra. A lei o determina como sendo um direito da pessoa natural. O direito do trabalho garante a aplicabilidade das normas jurídicas em defesa da pessoa humana, no âmbito empregatício, da qual a CF/88 já declarava como direitos personalíssimos.

\section{PROTEÇÃO JURÍDICA AO TRABALHADOR}

Na Justiça do Trabalho a doutrina se posiciona de maneira a indicar alguns pontos, que sugerem haver diferença entre dano moral e assédio Moral. Rufino (2010, p. 44) refere-se ao assédio moral como:

[...] existe um liame entre o assédio moral e a usurpação dos direitos da personalidade, da liberdade, da dignidade e do exercício da cidadania, pois as condutas vexatórias que configuram a violência perversa, denominada assédio moral, fatalmente ferirá o princípio maior do cidadão e os demais direitos ligados à sua moral.

Conforme Felker (2006, p. 18) "dano moral é todo ato que atinge direitos da personalidade do trabalhador, empregador, como pessoa física, de pessoa jurídica empregadora ou da coletividade, decorrente de violação à liberdade, honra, dignidade, intimidade, imagem, reputação, bom nome profissional e empresarial. " Neste leque de disposições, é caracterizado um esforço da Justiça do Trabalho para alinhar direito e ética nas 
relações laborais. Ou seja, o dano moral é de responsabilidade civil e implica em reparação. Nesse sentido, Minardi (2010) especifica:

\begin{abstract}
no Brasil não há lei especifica sobre o assunto no que se refere ao âmbito privado do direito do trabalho e por isso deve-se buscar nos princípios gerais do direito do trabalho e do direito ambiental (aqui incluída as normas legais de segurança e medicina do trabalho), bem como nos princípios fundamentais da República Federativa do Brasil.
\end{abstract}

Andrade (2006) afirma que há uma mudança de paradigma nos domínios da responsabilidade civil. Explica que a ideia tradicional em nosso direito de que a função da responsabilidade civil se limita à reparação do dano foi superada. Hoje, principalmente nos casos em que é atingido um direito da personalidade, entende-se que a responsabilidade civil não tem apenas o papel de reparar o dano, mas também o de punir o ofensor e prevenir outros

ilícitos. O Desembargador Nagib Slaibi, relator na apelação cível no 033653044.2008.8.19.0001 (2009.001.59366), do TJ-RJ, é a favor da indenização punitiva. O Desembargador corrobora a Andrade (2006) no sentido de que, no Brasil, a indenização por dano moral, em muitos casos, deve assumir caráter punitivo: quando o ofensor agiu com culpa consciente, malícia ou dolo. Em concordância, Nascimento (2009) aborda o conceito como:

Dano moral, que é o efeito da agressão moral, do assédio moral e do assédio sexual, é um só e mesmo conceito, no direito civil e no direito do trabalho, não existindo um conceito de dano moral trabalhista, que assim, vai buscar no direito civil os elementos da sua caracterização.

Não existe no ordenamento jurídico brasileiro, legislação própria acerca do assédio profissional e do assédio moral até o presente momento, porém existem dispositivos estaduais e municipais, bem como projetos de lei tramitando no Congresso Nacional, ainda aguardando aprovação. Na ausência de dispositivos específicos acerca do assunto, os magistrados se pautam em normativas que podem ser direcionadas para punição do dano moral, como a Constituição Federal, o Código Civil e à Consolidação das Leis do Trabalho (CLT) para embasar suas decisões. A CRFB (1988), inciso X contempla em sua redação:

Art. 5ํ. Todos são iguais perante a lei, sem distinção de qualquer natureza, garantindose aos brasileiros e aos estrangeiros residentes no País a inviolabilidade do direito à vida, à liberdade, à igualdade, à segurança e à propriedade, nos termos seguintes:

X - são invioláveis a intimidade, a vida privada, a honra e a imagem das pessoas, assegurado o direito a indenização pelo dano material ou moral decorrente de sua violação;

No Código de Processo Civil os artigos 186 e 187 do dispõe:

Art. 186. "Aquele que, por ação ou omissão voluntária, negligência ou imprudência, violar direto e causar dano a outrem, ainda que exclusivamente moral, comete ato ilícito".

Art. 187. "Também comete ato ilícito o titular de um direito que, ao exercê-lo, excede 
manifestamente os limites impostos pelo seu fim econômico ou social, pela boa-fé ou pelos bons costumes".

Art. 927. "Aquele que, por ato ilícito (art. 186 e 187), causar dano a outrem, fica obrigado a repará-lo".

Na Emenda Constitucional 45/2004, outras mudanças ocorreram conforme nova redação do art. 114 da Constituição Federal in verbis:

Art.114. Compete à Justiça do Trabalho processar e julgar: VI - as ações de indenização por dano moral ou patrimonial, decorrentes da relação de trabalho (CRFB, 1988).

Saraiva (2006), a esta redação da carta magna, faz aferição ao inciso do art. 114, sobre a competência material da Justiça do Trabalho para processar e julgar as ações de indenização por dano moral ou patrimonial, decorrentes da relação de trabalho.

O novo art. 114, VI da CF/1988 aplica o juízo ações por dano moral ou patrimonial peticionadas pelo empregado contra o empregador ou vice-versa, resultante da relação de trabalho, será de competência material da Justiça do Trabalho, posicionamento já adotado pelo Supremo Tribunal Federal- STF, mesmo antes da EC 45/04. Enquanto que, na CLT (Consolidação das Leis do Trabalho) Art. 483 - O empregado poderá considerar rescindido o contrato e pleitear a devida indenização quando: b) for tratado pelo empregador ou por seus superiores hierárquicos com rigor excessivo; e) praticar o empregador ou seus prepostos, contra ele ou pessoas de sua família, ato lesivo da honra e boa fama; f) o empregador ou seus prepostos ofenderem-no fisicamente, salvo em caso de legítima defesa, própria ou de outrem.

Na esfera Previdenciária as doenças ocupacionais, de origem psicológica como é a síndrome do Burnout, são reconhecidas como acidente de trabalho pelo NTEP (Nexo Técnico Epidemiológico Previdenciário ou NTEP é o método criado pela previdência social para auxiliar na caracterização de um acidente ou doença do trabalho), e tem previsão legal no anexo II do Decreto 3.048/99 no quadro de transtornos legais e do comportamento relacionados com o trabalho. Destarte, as previsões legais nas CCTs (Convenções Coletivas de Trabalho) e nas NRs (Normas Regulamentadoras) que norteiam os Laudos de Medicina e Segurança do Trabalho.

A dificuldade na formulação de leis que regulem a penalização por assédio deve-se ao fator da subjetividade da questão e da dificuldade para a verificação do nexo causal, ou seja, definir que a ocorrência do assédio levou ao adoecimento. Após longo período e diversas petições por dano moral, a Justiça do Trabalho entendeu a abrangência do conceito do dano moral, pois em muitos casos não há a ocorrência de sofrimento ou dor que afete o psicossomático da pessoa, porém não deixa de violar os direitos personalíssimos.

Atualmente a Justiça do Trabalho infere pacificamente, que ficando caracterizado dano moral é desnecessária a comprovação do dano patrimonial, gerando indenização por si só. A Súmula N. 37 do Superior Tribunal de Justiça traz claramente, "são cumuláveis as indenizações por dano material e dano moral oriundos do mesmo fato. " Do desenvolvimento 
da relação jurídico-contratual trabalhista emergem conflitos de variada abrangência e penetração em áreas diversas do direito, mas que, nem por isto, deixam de ter, como raiz originária, o contrato de trabalho.

Não obstante, a inter-relação com outros ramos da ciência jurídica, não se desnatura a natureza típica ou materialmente trabalhista de tais litígios, a exemplo do atinente à indenização por dano moral, inserindo-se o seu exame e julgamento, no âmbito da competência da Justiça do Trabalho, pois assim autoriza a interpretação do art. 114 da CF/88." TRT 3ạ Região - Rec. Ord. 6.537 - Rel.: Juíza Denise ALVES HORTA - j. em 16.09.96 - DJ de 05/10/96.

Entende-se que há grandes possibilidades das pessoas em seu labor, causarem prejuízos umas ás outras, porém há princípios jurídicos que norteiam as relações entre empregados e empregadores. Quando não há entendimento na relação de emprego com atos equivocados e abusivos, se estabelece uma via de mão dupla para ambas as partes. "O ato ilícito da conduta ofensiva caracteriza, na realidade, uma violação contratual que desloca o ônus da prova ao ofensor. " (FELKER, 2006, p. 77).

Na maioria das vezes o dano não é comprovado e os petições não condizem com a realidade dos fatos, caracterizando, dessa forma, pedidos abusivos. Quando comprovado se torna necessária a aferição do dano, tem-se que a violação de um dever legal de comportamento mostra, objetivamente, que houve invasão da esfera de atuação legítima do interessado lesado. A tarefa mais difícil no ordenamento jurídico é fixar o valor a ser ressarcido em virtude do dano moral evidenciado. Assim, nos termos do art. 944, do Código Civil: Art. 944. "A indenização mede-se pela extensão do dano".

A reforma trabalhista introduzida pela lei $13.467 / 17$, que entrou em vigor no último dia 13 de novembro de 2017 e, estipula o valor da indenização por dano moral baseado na gravidade e no salário do colaborador. A reforma estipula quatro categorias de ofensas: de natureza leve (até três vezes o último salário do ofendido), média (até cinco vezes o último salário), grave (até vinte vezes o último salário) e gravíssima (até cinquenta vezes o último salário). Segundo Fleury (2018):

estabeleceu-se, por norma infraconstitucional, limites para quantificação em Juízo dos danos imateriais, criando faixas de reparação segundo a natureza e gradação da lesão - leve, média, grave e gravíssima - e, em cada estreito, um limite máximo, inicialmente atrelado ao próprio salário do empregado ofendido (CLT, art. 223-G e $\S \S)$. Instituiu-se, assim, o dano moral tarifado na esfera das relações de trabalho.

Por meio da Medida Provisória (MP) 808, de 14 de novembro de 2017, o governo tentou amenizar o que já fora antes implementado, mantendo a tarifação, mas sem utilizar o paradigma salarial como base de cálculo e, sim, teto máximo dos benefícios do Regime Geral da Previdência. Agora, de acordo com a MP 808/17 os magistrados deverão aferir de três, cinco, vinte e cinco e cinquenta vezes o valor do limite do teto máximo dos benefícios do Regime 
Geral de Previdência Social, de acordo com a natureza da ofensa - leve, média, grave e gravíssima. Neste contexto, os juristas do direito do trabalho tem a preocupação em monitorar as normas laborais e assegurar o direito à dignidade das partes envolvidas nas relações trabalhistas.

\section{LITIGÂNCIA DE MÁ-FÉ POR DANO MORAL}

É redundante salientar que as varas da justiça do trabalho estão saturadas de ações e a maioria delas é por dano moral, das quais requerem maior cautela por parte dos magistrados ao julgar. Os empregados pleiteiam ações de dano moral por qualquer motivo, virou modismo, onde os próprios juristas qualificados aceitam as causas somente para garantir seus honorários. Isso ocorre porque ao longo do tempo as petições por dano moral desencadearam uma grande repercussão econômica, de forma banalizada apenas visando lucro, sendo necessária a aplicação da multa por litigância de má-fé de ofício. Para Neves (2004), tem-se que:

\footnotetext{
Dano moral - Banalização - Em se tratando de pedido de indenização decorrente de dano moral, deve ser adotada uma postura extremamente cuidadosa diante de situações rotuladas como causas desencadeadoras, sob pena de banalização do reconhecimento do dano moral, que em nada vem prestigiar as reais situações em que tal espécie de dor se verifica, comprometendo, desse modo, a credibilidade do art. 5.. , inc. $X$ da CF/88.93.
}

A justiça trabalhista julga de forma punitiva em face do empregador respeitando o fundamento do hipossuficiente, considerando os direitos personalíssimos expressos na CF/88.

No entanto muitas vezes o dano moral alegado não está ligado a intimidade da pessoa, sequer gerou qualquer tipo de abalo psicológico, não ferindo o direito da personalidade. Neste caso os magistrados aplicam a litigância de má-fé, decretando improcedência do pleito. $\mathrm{O}$ doutrinador Nelson Nery Júnior conclui que a motivação da sentença pode ser analisada por vários aspectos que vão desde a necessidade de comunicação judicial, exercício de lógica e atividade intelectual do juiz, até sua submissão, como ato processual, ao estado de direito e às garantias constitucionais estampadas no art. 5ㅇ, CF/88, trazendo à exigência de imparcialidade do juiz, a legalidade da mesma decisão, passando pelo princípio constitucional da independência jurídica do magistrado, que pode decidir de acordo com sua livre convicção.

Frente a essas inevitáveis situações faz-se necessário observar o art. 17 do CPC (Para postular em juízo é necessário ter interesse e legitimidade), onde se refere ao ponto de vista fático, e em que condições os pedidos de levianos de indenização por danos morais devem ser punidos como litigância de má-fé. Conforme o CPC (2015):

Art. 79. Responde por perdas e danos àquele que litigar de má-fé como autor, réu ou interveniente.

Art. 80. Considera-se litigante de má-fé aquele que: 
I - deduzir pretensão ou defesa contra texto expresso de lei ou fato incontroverso;

II - alterar a verdade dos fatos;

III - usar do processo para conseguir objetivo ilegal;

Art. 81. De ofício ou a requerimento, o juiz condenará o litigante de má-fé a pagar multa, que deverá ser superior a um por cento e inferior a dez por cento do valor corrigido da causa, a indenizar a parte contrária pelos prejuízos que esta sofreu e a arcar com os honorários advocatícios e com todas as despesas que efetuou.

Tem-se ciência que na maioria das reclamatórias trabalhistas o dano moral é sempre o petição principal, porém nem sempre corresponde com a veracidade dos fatos.

Os magistrados aplicam penalidades para reduzir as ações, oriundas da má fé, quando concluem que as ações pleiteadas são apenas fatos infundados, sem provas concretas caracterizando assim apenas desejos por uma indenização ilícita.

Para Hirigoyen (2006, p. 348) "apesar de tudo, a justiça jamais poderá reparar o sofrimento das vítimas. É, pois, importante não nos limitarmos aos regulamentos e às leis, sob o risco de cairmos na juridicidade excessiva; é preciso insistir na prevenção".

\section{PREVENÇÃO DAS AGRESSÕES NO AMBIENTE LABORATIVO}

O poder empregatício é um conjunto de privilégios assegurados pela justiça, centralizado no empregador, para desenvolvimento atividades nas ralações de emprego. (DELGADO. 2004, p. 629). Para a justiça do trabalha entende-se que a subordinação é um dos principais fatores para configuração de uma relação de emprego, onde o empregador exerce seu poder diretivo para nortear as funções desenvolvidas em sua empresa.

Segundo Minardi (2010) “o poder do empregador, que dá azo à subordinação jurídica caracterizadora da relação de emprego, não é ilimitado e não pode ser considerado um direito absoluto decorrente da propriedade privada". O empregador deve proceder de acordo com a Constituição Federal e todas as normativas legais que regulam as relações de emprego, as quais visam proteger a saúde física e mental dos trabalhadores, respeitando a dignidade do ser humano.

Pessanha (2018) enfatizou que "proporcionar ao empregado um ambiente de trabalho salubre ou - quando muito - providenciar para que condições desgastantes e nocivas à sua saúde sejam neutralizadas, é obrigação do empregador". Orientar as atividades laborais de forma que a convivência diária seja baseada no respeito ao ser humano, delimitando o poder diretivo segundo as normativas vigentes no contrato de trabalho e observando os limites físicos e psicológicos de cada colaborador.

O assédio moral implica em um risco á saúde física e mental, podendo ser enquadrado como doença do trabalho com legislação prevista no art. 20 da lei 8.213/91 da Previdência 
Social. São ações de comportamento simples de razoabilidade e respeito devem nortear as relações de trabalho proporcionado um ambiente laborativo saudável, conservando a primazia da realidade, onde o empregado sempre é a parte mais fraca no contrato de trabalho.

\section{CONSIDERAÇÕES FINAIS}

Esta discussão teórica aprofundou o tema de como o dano moral afeta a vida dos trabalhadores e compreendeu a sua importância sob o olhar do Direito trabalhista, pois reflete nos fatores que levam os colaboradores a ter baixa produtividade, desmotivação e problemas de saúde de ordem física e mental.

A qualidade de vida laboral é o resultado de um conjunto de fatores bons ou ruins presentes no ambiente organizacional. Depende de um poder diretivo equilibrado e qualificado, de bom senso, de respeito mútuo e de observação criteriosa da legislação vigente.

Configura-se o dano moral quando são agredidos à intimidade, à vida privada, à imagem e a honra, causando desconforto, intimidação e constrangimentos, lesando direitos personalíssimos. O dano moral é realidade nos ambientes laborais e apesar de todos os problemas de saúde e psicológicos que ele causa, muitos permanecem desempenhando suas funções em virtude da dificuldade financeira.

O silêncio dos colegas e encarregados é um ato de sadismo, de covardia e de medo, validado pelo fato de não quererem se envolver na problemática. Estes silêncios, mediante as situações inquiridas, acabam por enaltecer o agressor, que continua com o mesmo comportamento sem ser punido.

Observando a legislação trabalhista, muitos são os dispositivos utilizados para indenização do dano moral como forma de punição ao agressor, e serve como alerta para contemplação das normativas que regulam as relações entre empregados e empregadores.

Deste modo, compete aos magistrados a tarefa de avaliar as circunstâncias do caso, a gravidade do dano, a situação do lesante, a condição do lesado, preponderando, em nível de orientação central, a ideia de sancionamento ao lesante. Em conformidade com Caldas (2017) o Juiz:

[...] deverá analisar o caso levando em consideração critérios como a intensidade do sofrimento ou da humilhação da vítima; a possibilidade de superação física ou psicológica; os reflexos pessoais e sociais; a extensão e a duração dos efeitos da ofensa; as condições em que ocorreu tal ofensa; o grau de culpa do acusado; a situação social e econômica das partes envolvidas e o grau de publicidade da ofensa, entre outros.

O dano moral é uma tipificação de agressões vivenciadas por inúmeros trabalhadores, dos quais a maioria prefere, após o desligamento do vínculo de emprego, somente esquecer e recomeçar novamente. Muitas vezes os danos físicos e psicológicos serão marcas existenciais 
que serão suportadas durante toda a vida com medicação de uso contínuo, extinguindo a possibilidade de uma vida laboral normal. Ou seja, é necessária a conscientização as classes para que realmente se pratique o respeito aos direitos personalíssimos, tanto difundidos pela $\mathrm{CF} / 88$, mas principalmente o respeito ao ser humano.

Considera-se que a legislação trabalhista busca oferecer proteção ao trabalhador, considerado o elo mais fraco, nas relações de emprego, onde o princípio da boa-fé objetiva é aplicado pelos magistrados em todas as áreas do direito e sua função é estabelecer um padrão ético de conduta para as partes envolvidas.

A valoração do dano moral tem por finalidade amenizar o sofrimento da vítima, como reparação ao desgaste físico e psicológico, com a intenção de reprimir a conduta do agressor e desta forma garantir a efetividade aos princípios fundamentais, sobretudo o princípio da dignidade da pessoa humana.

\section{REFERÊNCIAS}

ALCADIPANI, Rafael; TURETA, César. Perspectivas críticas no Brasil: entre a "verdadeira crítica" e o dia a dia. CADERNOS EBAPE. BR, v. 7, no 3, artigo 7, Rio de Janeiro, Set. 2009.

ANDRADE, André Gustavo Corrêa. Dano Moral e Indenização Punitiva. Rio de Janeiro: Forense, 2006.

AGUIAR. André Luiz Souza. Assedio Moral: O direito a indenização pelos maus tratos sofridos no ambiente de trabalho. São Paulo, 2005.

BARROS, Alice Monteiro de. Proteção à Intimidade do Empregado. São Paulo: LTr, 1997.

BRASIL. Constituição (1988). Diário Oficial da República Federativa do Brasil. Brasilia, DF, 5 Outubro 1988.

BARRETO, Margarida M. S.Violência, Saúde, Trabalho: uma jornada de humilhações. 1.ed. São Paulo: EDUC, 2003.CAMARGO.

CALDAS, Edson. Reforma trabalhista: indenização por dano moral será limitada e baseada no salário da vítima. 2017. Disponível em:

<https://epocanegocios.globo.com/Carreira/noticia/2017/07/reforma-trabalhista-

indenizacao-por-dano-moral-sera-limitada-e-baseada-no-salario-da-vitima.html>. Acesso em: 21 fev 2018.

CERVO, Amado Luiz; BERVIAN, Pedro Alcino. Metodologia Científica. 4. ed. São Paulo: Makron Books, 1996.

CLT. Consolidação das Leis do Trabalho, 1943. Disponível em: <www. planalto.gov>. Acesso em 21dez 2017. 
CPC. Código de Processo Civil, 2015. Disponível em: <www. planalto.gov>. Acesso em 16 jan 2018.

CRFB. Constituição da República Federativa do Brasil, de 05 de outubro de 1988. Disponível em: <www. planalto.gov>. Acesso em 16 jan 2018.

CUNHA Fo, Walter Xavier. O dano moral decorrente do descumprimento das obrigações trabalhistas. 2012. Disponível em: https://jus.com.br/artigos/22185/o-dano-moraldecorrente-do-descumprimento-das-obrigacoes-trabalhistas/1. Acesso em 02 fev 2018.

DIONÍZIO. Sônia das Dores, Rel. Juíza. TRT - 17ạ Região - RO 1315.2000.00.17.00.1 - Ac. 2276/2001.

DELGADO, Mauricio Godinho. Curso de Direito do Trabalho. 3. ed. São Paulo: LTr, 2004. p. 629.

DELGADO, Mauricio Godinho. Curso de Direito do Trabalho. 16. ed. rev. e ampl. São Paulo: LTr, 2017.

FELKER. Reginaldo. O dano moral, o assédio moral e o assédio sexual nas relações de trabalho. São Paulo: LTr, 2006.

FLEURY, Renata. O dano moral na Reforma Trabalhista. Inconformidade constitucional. 2018. Disponível em: http://www.migalhas.com.br/dePeso/16,MI271868,81042-

O+dano+moral+na+Reforma+Trabalhista+Inconformidade+constitucional. Acesso em: 21 fev 2018.

HIRIGOYEN, Marie-France. Mal-estar no trabalho. 3a ed. Rio de Janeiro: Bertrand Brasil, 2006.

HIRIGOYEN, Marie-France. Assédio moral: a violência perversa no cotidiano. 5a ed. Rio de Janeiro: Bertrand Brasil; 2002.

HIRIGOYEN, Marie-France, Assédio Moral: a violência perversa mo cotidiano. Tradução de Maria Helena Kuhner. 6a ed. Rio de Janeiro: Bertrand Brasil, 2003.

HORTA, Denise Alves, Rel.: Juíza. TRT 3a Região - Rec. Ord. 6.537.

JÚNIOR. José Herval Sampaio, A litigância de má-fé no novo CPC. O que fazer para tornar tal prática exceção? 2016. Disponível em:

https://joseherval.jusbrasil.com.br/artigos/229832161/a-litigancia-de-ma-fe-no-novo-cpc-oque-fazer-para-tornar-tal-pratica-excecao. Acesso em: 20 fev 2018.

JUNIOR, Nelson Nery. Princípios de Processo Civil na Constituição Federal, RT, 4a edição, p. $170 / 171$

LOBO, Hewdy. Qual a Diferença entre Assédio Moral e Dano Moral?. 2016. Disponível em: https://lobo.jusbrasil.com.br/artigos/253200355/qual-a-diferenca-entre-assedio-moral-edano-moral\#comments. Acesso em: 13 fev 2018. 
MARCONI, Marina de Andrade; LAKATOS, Eva Maria. Metodologia científica. São Paulo: Atlas, 2006.

MARRAS. Jean Pierre. Administração de Recursos Humanos: do operacional ao estratégico. 15. Ed.. São Paulo: Saraiva, 2016.

MINAYO, Maria Cecília de Souza; et. al. Caminhos do pensamento: epistemologia e método. Rio de Janeiro: Fiocruz, 2002.

MORAES. Solana, Trabalho: Você sofre com Assédio Moral, Mobbing ou Burnout?. 2013. Disponível em: <https://solanamoraes2013.jusbrasil.com.br/artigos/220728532/trabalhovoce-sofre-com-assedio-moral-mobbing-ou-burnout>. Acesso em 20 jan 2018.

NASCIMENTO, Sônia Mascaro. Assédio Moral. São Paulo: Saraiva, 2009.

NEVES, Nélia. Da Banalização do Dano Moral. TRT 5. a R. - RO 01472-2000-551-05-85-7 (1.314/04) - 4. a T. - Rel.a Juíza Nélia Neves - J. 27.01.2004). Disponível em: <http://www.tribunapr.com.br/noticias/da-banalizacao-do-dano-moral/>. Acesso em: 04 mar. 2018.

RUFINO, Regina Célia Pezzuto. Assédio Moral no âmbito da Empresa. 3. ed. São Paulo: LTr, 2011.

SARAIVA, Renato. Curso de Direito Processual do Trabalho. 3.ed. rev. e atual. São Paulo: Método, 2006.

TRIBUNAL REGIONAL DO TRABALHO. 4a Turma 5. a R. - RO 01472-2000-551-05-85-7. Relatora: Juíza Nélia Neves. J. 27.01.2004. Disponível em:

<file://D:/Usu\%C3\%A1rio/Downloads/Vasconcelos_2015_Assedio-moral-nos-ambientesco_37763.pdf >. Acesso em: 20 jan 2018. 